\title{
A közlekedési szokásjellemzók alakulása, hatásuk a személygépkocsi-forgalomra
}

\begin{abstract}
Az új Országos Célforgalmi Mátrix (OCM-2016) személygépkocsi-rétegének megalapozását szolgáló háztartási megkérdezések alapján megállapítható, hogy a lakosság közlekedési szokásai számos aspektusból figyelemre méltóan megváltoztak a 2008as hasonló felmérés óta eltelt időben. Nött a személygépkocsival megtett helyközi utazások átlagos hossza, csökkent ugyanakkor a személygépkocsik telítettsége. Az utazók közlekedési eszköz választásában, illetve a helyközi utazások indokaiban nem tapasztaltunk jelentős átrendeződést, s a helyközi utazások gyakorisága
\end{abstract} sem változott szignifikánsan.

DOI 10.24228/KTSZ.2017.5.4

\section{Dr. Siska Miklós - Szúcs Hajnalka}

e-mail: siska.miklos@kti.hu

\section{BEVEZETÉS}

A közlekedési szokásjellemzők - mint ahogyan az emberek szokásai általában - változnak az idők folyamán. Ugyanakkor a szokások átalakulása általában lassabb, mint pl. a divatirányzatok akár évenkénti módosulásai. A szokások az idő előrehaladtával egyenesen tradícióvá „merevedhetnek”.

A közlekedési szokások egy része, mint például a még elfogadott napi ingázási idő kimondvakimondatlanul tradíciónak tekinthető. Megfigyelhető, hogy térben és időben is - akár egymástól távol fekvő területeken is - érvényes az a megfigyelés, hogy a napi hivatásforgalomban eltöltött idő az esetek döntő hányadában nem haladja meg egy-egy irányban az egyórás időtartamot. A régi korok embere sem tudott több időt szánni munkahelye megközelítésé- re egy óránál, s a mai megapoliszok lakosai is legfeljebb ennyi időt fordítanak a munkába járásra [1-2].

Természetesen igaz ez Magyarországon is a fövárosban, a falvakban, közforgalmú közlekedési eszközt vagy egyéni közlekedési módot választva, az utazók általában legfeljebb hatvanpercnyi távolságból közelítik meg munkahelyüket, iskolájukat ${ }^{1}$. A nap régen is és ma is csak huszonnégy órából áll mindenkinek, ha ebből két óránál többet töltenének utazással, akkor vagy a munkára, vagy a pihenésre nem maradna elengedő idő. Ugyanakkor az átlagos utazási sebesség emelkedése sokszorosára növelheti egy-egy vonzásközpont körül az ingázó öv kiterjedését.

A közlekedési szokások egy másik része viszont egyénenként és nagy tömegben is vi- 
szonylag gyorsan módosulhat. Ilyen lehet például az ügyintézésre, vásárlásra fordított idő. $\mathrm{Az}$ internetes alkalmazások térhódításával egyre több dolgot lehet a számítógéppel intézni: banki és állampolgári ügyek, adózás, vásárlás stb. $S$ ezekkel az alkalmazásokkal nem csak a hivatali sorban állás ideje, de az iroda elérésének ideje is megtakarítható. $S$ ami ezzel együtt jár, az adott célú utazások aránya csökkenhet az összes helyváltoztatáson belül [3].

Nemcsak az utazások indoka, de az összes utazáson belül a közlekedési módok egymáshoz viszonyított aránya is átalakuláson megy át az idők folyamán. Gondoljunk csak arra, hogy az európai légtér liberalizációja nyomán megjelenő ún. „fapados” légitársaságok hogyan alakították át az utazási szokásokat [4]. Milyen dinamikusan megnőtt például a néhány napos városlátogatások iránti kereslet, vagy mennyivel többen utaznak repülőgéppel nyaralni személygépkocsi helyett. (S persze személygépkocsit bérelnek úti céljukon.) Ugyanígy a nagysebességü vasúti hálózat kiépülése is jelentős befolyással van a közlekedési mód megválasztására, versenyképessé téve a kötöttpályás közlekedést a személygépkocsival, illetve a rövid (500-800 km-nél rövidebb) repülőutakkal szemben is.

A közlekedési szokásjellemzők fontos elemei a közlekedési áramlások modellezésének és elörejelzésének. Éppen ezért szükséges nyomon követni alakulásukat, hiszen ha nem vesszük figyelembe ezeket a változásokat, akkor könynyen téves következtetésekre juthatunk sokmilliárdos infrastruktúra-beruházások előkészítése során.

Az ismertetés a következő módon épül fel: bemutatjuk az alkalmazott módszertantant, a felmért járások népességének jellemzőit, közlekedési szokásait, valamint a 2008. és 2016. évi háztartási megkérdezések alapján a közlekedők helyközi mobilitásának, módválasztásának, utazásai indokainak és gyakoriságának alakulását, változásait. Az írást a tanulságok összefoglalása zárja.

\section{MÓDSZERTAN}

2008-ban, a Bevezetésben hivatkozott munkához átfogóbb vizsgálatot végeztünk. Akkor az ország - Budapesten kívüli területének - közel felét be tudtuk vonni felmérésünkbe. Mintegy 24 ezer háztartásban több mint 52 ezer személyt kerestek fel a kérdezőbiztosok. 2016-ban a rendelkezésünkre álló források ennél jóval kisebb arányú kikérdezést tettek csak lehetővé, így mindössze 16 olyan járásban végeztünk háztartási kikérdezést, amelyekben 2008-ban is felmértük - többek között - a lakosság közlekedési szokásait. Ennek megfelelően a felkeresett háztartások és személyek száma is jóval kevesebb volt, mindössze 4707 háztartás 9281 tagját kérdeztük meg. A felmérésbe bevont járásokat és településeket azonban ezúttal is úgy választottuk meg, hogy mintánk változatlanul tükrözze az ország egészére jellemző arányokat.

A háztartási kikérdezések során megkérdezettek - a kikérdezendő háztartások véletlenszerű kiválasztásából következően - nem minden szociológiai jellemzőjük szerint tükrözik pontosan a felmért járások teljes lakosságát. Éppen ezért az egyes válaszadók neme, kora stb. alapján súlyozni kellett a kapott válaszokat. Az így kialakított adatbázisunk alapján képeztük a különböző viszonyszámokat. Így a súlyozott adatok már nem, kor és a lakóhely típusa szerint is pontosan adják vissza a megkérdezett járások lakosságára jellemző arányokat.

A felkeresett háztartások tagjainak csak a kérdezést megelőző napon lebonyolított utazásaira voltunk kíváncsiak. Korábbi adatfelvételeinkből tudjuk ugyanis, hogy az emberek általában még az előző napi utazásaikra sem emlékeznek mindig pontosan, s ahhoz képest még további kb. 30\%-os adatvesztéssel kellene számolnunk akkor, ha a kérdezést két nappal megelőző utazásaikat is kérdeztük volna. A válaszadóknak többek között az utazás kiinduló és céltelepülését, utazásuk kezdetének óráját, az utazás indokát, a használt közlekedési eszközt, személygépkocsi esetén a díjfizetős útszakasz igénybevételét és a használt „matricát” kellett megadniuk a szokásos személyes adatokon felül (nem, életkor, gazdasági aktivitás, iskolai végzettség stb.) 
A súlyozott válaszok alapján számítottuk mintánkban az egyes közlekedési szokásjellemzőket. Az egy före jutó mobilitási adatokat, illetve az utazások közlekedési módok szerinti megoszlását hasonlítottuk össze egyes járásokban a 2008. évi, hasonló tartalommal elvégzett felmérésünk eredményeivel. Emellett vizsgáltuk a kapott adatok átlagos értékeit és az egyes jellemzők szórását.

Mivel korábbi és mostani felmérésünkben a háztartások és a megkérdezett személyek kiválasztásának módszere és az alkalmazott kérdőív is majdnem azonos volt, az eredményeket a jól ismert statisztikai próbákkal hasonlíthattuk össze. Ennek során $\mathrm{H}_{0}$ hipotézisünk minden esetben az volt, hogy a két különböző időpontból származó felmérés átlagos értéke és szórása nem tér el egymástól szignifikánsan, alternatív $\mathrm{H}_{1}$ hipotézisünk pedig az volt, hogy a két minta (hiszen a felmérések eredménye minden esetben az egyes járások lakosságára vonatkozóan csak mintának tekinthetö) átlaga és szórása is szignifikánsan eltér egymástól. A hipotézisek ellenőrzésére a statisztikában jól ismert t-próbát és F-próbát alkalmaztuk.

Mivel az eredményeket befolyásoló tényezőkre is kíváncsiak voltunk, a hipotézisellenőrzést a válaszadók többféle szociológiai szempont szerinti szegmentálása után is elvégeztük. Azt kerestük ugyanis, hogy a különböző időpontokban végzett felmérések alapján számított közlekedési szokásjellemzők azonosságára, illetve különbözőségére hatással van-e a népesség demográfiai, aktivitási stb. összetételének változása. Más szavakkal: mik azok a tényezők, amelyek indokolják/magyarázzák a két különböző időpontban végzett felmérés alapján levonható következtetések eltérését, avagy egyezőségét.

\section{A MINTÁKBAN SZEREPLÖ LA- KOSSÁG JELLEMZÖI}

Terjedelmi okokból a következőkben csak a 2016. évi megkérdezésekben szereplő háztartások és lakosság jellemzőit vázoljuk, a 2008. évi felmérés adatait korábbi írásokban mutattuk be (pl. [5]). Mivel az egyes járásokban mindkét időpontban csak a kikérdezendő háztartások számát rögzítettük elöre, a ténylegesen kapott válaszok száma természetesen némileg eltér egymástól az egyes járásokban. Tekintve, hogy mindegyik járásban elegendöen nagy volt az átlagos háztartásnagyság (öszszességében 2,49 fö/háztartás, amely 2,13 fö/ háztartás és 2,72 fö/háztartás között szóródott), mintánk megbízhatósága 95,1\%-95,5\% közötti.

\begin{tabular}{|c|c|c|c|c|}
\hline \multirow{2}{*}{$\begin{array}{l}\text { Kistérség (2008) } \\
\text { / Járás (2016) }\end{array}$} & \multicolumn{2}{|c|}{ Nő } & \multicolumn{2}{|c|}{ Férfi } \\
\hline & 2008 & 2016 & 2008 & 2016 \\
\hline Ceglédi & $53 \%$ & $52 \%$ & $47 \%$ & $48 \%$ \\
\hline Csornai & $50 \%$ & $50 \%$ & $50 \%$ & $50 \%$ \\
\hline Gyáli & $53 \%$ & $51 \%$ & $47 \%$ & $49 \%$ \\
\hline Hajdúszoboszlói & $52 \%$ & $53 \%$ & $48 \%$ & $47 \%$ \\
\hline Hatvani & $53 \%$ & $50 \%$ & $47 \%$ & $50 \%$ \\
\hline Kisbéri & $54 \%$ & $50 \%$ & $46 \%$ & $50 \%$ \\
\hline Kunszentmiklósi & $51 \%$ & $49 \%$ & $49 \%$ & $51 \%$ \\
\hline Marcali & $52 \%$ & $51 \%$ & $48 \%$ & $49 \%$ \\
\hline Soproni & $52 \%$ & $51 \%$ & $48 \%$ & $49 \%$ \\
\hline Sümegi & $53 \%$ & $50 \%$ & $47 \%$ & $50 \%$ \\
\hline Szeged város & $59 \%$ & $53 \%$ & $41 \%$ & $47 \%$ \\
\hline Szegedi & $52 \%$ & $50 \%$ & $48 \%$ & $50 \%$ \\
\hline $\begin{array}{l}\text { Székesfehérvár } \\
\text { város }\end{array}$ & $52 \%$ & $58 \%$ & $48 \%$ & $42 \%$ \\
\hline Székesfehérvári & $53 \%$ & $53 \%$ & $47 \%$ & $47 \%$ \\
\hline Szekszárdi & $52 \%$ & $51 \%$ & $48 \%$ & $49 \%$ \\
\hline Szerencsi & $54 \%$ & $51 \%$ & $46 \%$ & $49 \%$ \\
\hline Összesen & $53 \%$ & $51 \%$ & $47 \%$ & $49 \%$ \\
\hline
\end{tabular}

Felmérésünket összehasonlítva a 2008. évi adatokkal azt állapítottuk meg, hogy a mintáinkban szereplő járásokban kismértékben nőtt a férfiak (1. táblázat), illetve a fiatalabb (30 éves alatti) korosztályok aránya (2. táblázat). Ez utóbbi módosulás alapvetően az idősebb, 60 év fölöttiek terhére következett be. A változások - néhány járástól és korosztálytól eltekintve - azonban nem tekinthetök szignifikánsnak, általában a minták statisztikai hibahatárain belül maradnak. 
2. táblázat: A 2008-ban és 2016-ban is felmért térségekben megkérdezettek megoszlása életkori csoportok szerint

\begin{tabular}{|c|c|c|c|c|c|c|c|c|}
\hline \multirow{2}{*}{$\begin{array}{l}\text { Kistérség (2008) } \\
\text { / Járás (2016) }\end{array}$} & \multicolumn{2}{|c|}{6 - 18 éves } & \multicolumn{2}{|c|}{19 - 30 éves } & \multicolumn{2}{|c|}{$31-45$ éves } & \multicolumn{2}{|c|}{46 - 60 éves } \\
\hline & 2008 & 2016 & 2008 & 2016 & 2008 & 2016 & 2008 & 2016 \\
\hline Ceglédi & $13 \%$ & $17 \%$ & $14 \%$ & $14 \%$ & $22 \%$ & $21 \%$ & $22 \%$ & $20 \%$ \\
\hline Csornai & $10 \%$ & $16 \%$ & $12 \%$ & $15 \%$ & $21 \%$ & $22 \%$ & $24 \%$ & $20 \%$ \\
\hline Gyáli & $9 \%$ & $17 \%$ & $16 \%$ & $15 \%$ & $22 \%$ & $23 \%$ & $24 \%$ & $21 \%$ \\
\hline Hajdúszoboszlói & $10 \%$ & $12 \%$ & $17 \%$ & $18 \%$ & $21 \%$ & $22 \%$ & $18 \%$ & $23 \%$ \\
\hline Hatvani & $8 \%$ & $15 \%$ & $15 \%$ & $13 \%$ & $20 \%$ & $20 \%$ & $22 \%$ & $22 \%$ \\
\hline Kisbéri & $4 \%$ & $11 \%$ & $22 \%$ & $20 \%$ & $15 \%$ & $24 \%$ & $29 \%$ & $21 \%$ \\
\hline Kunszentmiklósi & $13 \%$ & $17 \%$ & $13 \%$ & $13 \%$ & $21 \%$ & $23 \%$ & $20 \%$ & $19 \%$ \\
\hline Marcali & $14 \%$ & $11 \%$ & $16 \%$ & $15 \%$ & $17 \%$ & $22 \%$ & $24 \%$ & $22 \%$ \\
\hline Soproni & $10 \%$ & $11 \%$ & $16 \%$ & $16 \%$ & $22 \%$ & $25 \%$ & $21 \%$ & $23 \%$ \\
\hline Sümegi & $13 \%$ & $11 \%$ & $14 \%$ & $16 \%$ & $20 \%$ & $23 \%$ & $20 \%$ & $25 \%$ \\
\hline Szeged város & $12 \%$ & $13 \%$ & $11 \%$ & $22 \%$ & $21 \%$ & $20 \%$ & $16 \%$ & $21 \%$ \\
\hline Szegedi & $8 \%$ & $19 \%$ & $12 \%$ & $12 \%$ & $31 \%$ & $25 \%$ & $19 \%$ & $20 \%$ \\
\hline Székesfehérvár város & $9 \%$ & $16 \%$ & $11 \%$ & $14 \%$ & $27 \%$ & $25 \%$ & $28 \%$ & $19 \%$ \\
\hline Székesfehérvári & $11 \%$ & $14 \%$ & $12 \%$ & $16 \%$ & $20 \%$ & $22 \%$ & $24 \%$ & $24 \%$ \\
\hline Szekszárdi & $12 \%$ & $14 \%$ & $13 \%$ & $15 \%$ & $20 \%$ & $22 \%$ & $23 \%$ & $23 \%$ \\
\hline Szerencsi & $15 \%$ & $16 \%$ & $12 \%$ & $18 \%$ & $22 \%$ & $21 \%$ & $19 \%$ & $19 \%$ \\
\hline Összesen & $11 \%$ & $14 \%$ & $14 \%$ & $16 \%$ & $21 \%$ & $22 \%$ & $22 \%$ & $21 \%$ \\
\hline
\end{tabular}

Összességében feltételezhetjük, hogy a minták módosulásaira. (Ne feledkezzünk meg közben eltérő nemek és életkorok szerinti összetételé- természetesen arról, hogy mintáink mindkét nek változása nincs statisztikailag értékelhető időszakban - a súlyozás révén - hüen tükröhatással a közlekedési szokásjellemzők későb- zik a szóban forgó járások teljes lakosságának biekben leírt, a minták alapján feltételezhető jellemzőit!)

3. táblázat: A 2008-ban és 2016-ban is felmért térségekben megkérdezettek megoszlása iskolai végzettségüik szerint

\begin{tabular}{|l|c|c|c|c|c|c|c|c|}
\hline \multirow{2}{*}{ Kistérség (2008) / } & \multicolumn{2}{|c|}{ Általános iskola } & \multicolumn{2}{|c|}{ Szakmunkás képzo } & \multicolumn{2}{c|}{ Középfokú iskola } & \multicolumn{2}{|c|}{ Felsőfokú iskola } \\
\cline { 2 - 9 } & $\mathbf{2 0 0 8}$ & $\mathbf{2 0 1 6}$ & $\mathbf{2 0 0 8}$ & $\mathbf{2 0 1 6}$ & $\mathbf{2 0 0 8}$ & $\mathbf{2 0 1 6}$ & $\mathbf{2 0 0 8}$ & $\mathbf{2 0 1 6}$ \\
\hline Ceglédi & $35 \%$ & $35 \%$ & $31 \%$ & $35 \%$ & $25 \%$ & $25 \%$ & $9 \%$ & $5 \%$ \\
\hline Csornai & $36 \%$ & $31 \%$ & $33 \%$ & $34 \%$ & $23 \%$ & $23 \%$ & $8 \%$ & $12 \%$ \\
\hline Gyáli & $28 \%$ & $39 \%$ & $33 \%$ & $33 \%$ & $36 \%$ & $21 \%$ & $2 \%$ & $6 \%$ \\
\hline Hajdúszoboszlói & $38 \%$ & $45 \%$ & $30 \%$ & $31 \%$ & $24 \%$ & $17 \%$ & $8 \%$ & $7 \%$ \\
\hline Hatvani & $38 \%$ & $39 \%$ & $28 \%$ & $26 \%$ & $25 \%$ & $26 \%$ & $9 \%$ & $9 \%$ \\
\hline Kisbéri & $33 \%$ & $37 \%$ & $26 \%$ & $33 \%$ & $29 \%$ & $23 \%$ & $12 \%$ & $7 \%$ \\
\hline Kunszentmiklósi & $46 \%$ & $54 \%$ & $31 \%$ & $30 \%$ & $18 \%$ & $12 \%$ & $5 \%$ & $4 \%$ \\
\hline Marcali & $51 \%$ & $49 \%$ & $25 \%$ & $23 \%$ & $18 \%$ & $21 \%$ & $7 \%$ & $6 \%$ \\
\hline Soproni & $31 \%$ & $35 \%$ & $27 \%$ & $29 \%$ & $28 \%$ & $27 \%$ & $15 \%$ & $9 \%$ \\
\hline Sümegi & $41 \%$ & $41 \%$ & $34 \%$ & $25 \%$ & $19 \%$ & $27 \%$ & $6 \%$ & $7 \%$ \\
\hline Szeged város & $25 \%$ & $26 \%$ & $28 \%$ & $22 \%$ & $35 \%$ & $42 \%$ & $12 \%$ & $10 \%$ \\
\hline Szegedi & $24 \%$ & $34 \%$ & $43 \%$ & $28 \%$ & $27 \%$ & $31 \%$ & $6 \%$ & $7 \%$ \\
\hline Székesfehérvár város & $16 \%$ & $25 \%$ & $18 \%$ & $21 \%$ & $43 \%$ & $37 \%$ & $23 \%$ & $18 \%$ \\
\hline Székesfehérvári & $40 \%$ & $40 \%$ & $31 \%$ & $38 \%$ & $20 \%$ & $19 \%$ & $10 \%$ & $4 \%$ \\
\hline Szekszárdi & $33 \%$ & $40 \%$ & $26 \%$ & $33 \%$ & $27 \%$ & $17 \%$ & $14 \%$ & $10 \%$ \\
\hline Szerencsi & $47 \%$ & $46 \%$ & $20 \%$ & $30 \%$ & $23 \%$ & $20 \%$ & $11 \%$ & $5 \%$ \\
\hline Összesen & $35 \%$ & $39 \%$ & $29 \%$ & $29 \%$ & $26 \%$ & $24 \%$ & $10 \%$ & $8 \%$ \\
\hline
\end{tabular}


Ellentétben a nemek és életkori csoportok szerinti megoszlással a vizsgált járásokban (legalábbis a megkérdezéseink alapján) a lakosság iskolai végzettség szerinti megoszlása egyes esetekben olyan jelentős mértékben megváltozott (3. táblázat), hogy feltételezhetjük azt is, hogy a közlekedési szokásjellemzők nyolc év alatt bekövetkezett módosulása részben ezzel is magyarázható. A 16 járásból csak 5 olyan, ahol a megkérdezettek iskolai végzettség szerinti megoszlásában bekövetkezett módosulás egyik kategóriában sem éri el a szignifikanciaszintet. A legnagyobb változások a legfeljebb általános iskolai végzettségüek arányának növekedésében és a középfokú végzettségüek arányának csökkenésében figyelhetők meg.

Az életkori csoportok és a különböző iskolai végzettségű szegmensek közötti átrendeződések természetesen megmutatkoznak a megkérdezettek gazdasági aktivitás szerinti megoszlásában bekövetkező módosulásokban is. Mintáinkban jelentősen megnőtt a tanulók és a fizikai foglalkoztatottak aránya, míg a nyugdíjasok részesedése figyelemre méltó mértékben csökkent. Egyes járásokban számottevő mértékben csökkent a szellemi foglalkozásúak hányada (4. táblázat). Tekintve, hogy jelen felmérésünk igazolta az eltérő gazdasági aktivitású csoportok mobilitásának eltérését egymástól, a megkérdezettek körében ezen a téren bekövetkező változások is magyarázhatják az átlagos mobilitás változásait.

\section{A KÖZLEKEDÉSI SZOKÁSJEL- LEMZŐK VÁLTOZÁSAI 2008 ÉS 2016 KÖZÖTT}

Az első és legfontosabb megállapításunk az, hogy a helyközi mobilitás a megkérdezett járások lakosságának körében jelentősen megváltozott 2008. évi kikérdezésünkkel összehasonlítva. A megkérdezések alapján azok aránya, akik egyáltalán nem utaztak el lakóhelyükről másik településre (2008-ban: 54\% - 76\% között) növekedett az elmúlt években (2016-ban: 55\% - 82\% között). Természetesen ezzel párhuzamosan mérséklődött a más településekre elutazók aránya, közöttük az ingázásra is jellemző napi kétszeri helyközi utazást lebonyolítóké csökkent leginkább. Ebben élen járnak a Sümegi, a Soproni, a Szerencsi, a Hatvani és a Csornai járások lakói, valamint Székesfehérvár városának polgárai.

4. táblázat: A 2008-ban és 2016-ban is felmért térségekben megkérdezettek megoszlása gazdasági aktivitásuk szerint

\begin{tabular}{|l|c|c|c|c|c|c|c|c|c|c|}
\hline \multirow{2}{*}{ Kistérség (2008) / } & \multicolumn{2}{|c|}{ Tanuló } & \multicolumn{2}{|c|}{ Szellemi fogl. } & \multicolumn{2}{|c|}{ Fizikai fogl. } & \multicolumn{2}{|c|}{ Inaktív } & \multicolumn{2}{c|}{ Nyugdíjas } \\
\hline & $\mathbf{2 0 0 8}$ & $\mathbf{2 0 1 6}$ & $\mathbf{2 0 0 8}$ & $\mathbf{2 0 1 6}$ & $\mathbf{2 0 0 8}$ & $\mathbf{2 0 1 6}$ & $\mathbf{2 0 0 8}$ & $\mathbf{2 0 1 6}$ & $\mathbf{2 0 0 8}$ & $\mathbf{2 0 1 6}$ \\
\hline Ceglédi & $16 \%$ & $27 \%$ & $12 \%$ & $6 \%$ & $25 \%$ & $31 \%$ & $10 \%$ & $7 \%$ & $38 \%$ & $29 \%$ \\
\hline Csornai & $13 \%$ & $24 \%$ & $9 \%$ & $10 \%$ & $31 \%$ & $30 \%$ & $7 \%$ & $6 \%$ & $39 \%$ & $29 \%$ \\
\hline Gyáli & $11 \%$ & $25 \%$ & $28 \%$ & $10 \%$ & $20 \%$ & $31 \%$ & $7 \%$ & $12 \%$ & $35 \%$ & $23 \%$ \\
\hline Hajdúszoboszlói & $15 \%$ & $23 \%$ & $8 \%$ & $10 \%$ & $22 \%$ & $29 \%$ & $13 \%$ & $14 \%$ & $43 \%$ & $24 \%$ \\
\hline Hatvani & $12 \%$ & $22 \%$ & $7 \%$ & $9 \%$ & $27 \%$ & $31 \%$ & $10 \%$ & $6 \%$ & $45 \%$ & $32 \%$ \\
\hline Kisbéri & $13 \%$ & $19 \%$ & $15 \%$ & $12 \%$ & $29 \%$ & $31 \%$ & $7 \%$ & $10 \%$ & $36 \%$ & $27 \%$ \\
\hline Kunszentmiklósi & $17 \%$ & $22 \%$ & $7 \%$ & $5 \%$ & $27 \%$ & $32 \%$ & $10 \%$ & $13 \%$ & $40 \%$ & $28 \%$ \\
\hline Marcali & $16 \%$ & $19 \%$ & $9 \%$ & $11 \%$ & $23 \%$ & $23 \%$ & $13 \%$ & $15 \%$ & $38 \%$ & $32 \%$ \\
\hline Soproni & $13 \%$ & $20 \%$ & $15 \%$ & $12 \%$ & $26 \%$ & $31 \%$ & $6 \%$ & $11 \%$ & $39 \%$ & $26 \%$ \\
\hline Sümegi & $16 \%$ & $24 \%$ & $8 \%$ & $14 \%$ & $25 \%$ & $25 \%$ & $10 \%$ & $11 \%$ & $41 \%$ & $26 \%$ \\
\hline Szeged város & $17 \%$ & $26 \%$ & $15 \%$ & $15 \%$ & $17 \%$ & $24 \%$ & $5 \%$ & $9 \%$ & $46 \%$ & $26 \%$ \\
\hline Szegedi & $11 \%$ & $28 \%$ & $19 \%$ & $14 \%$ & $29 \%$ & $25 \%$ & $3 \%$ & $8 \%$ & $38 \%$ & $25 \%$ \\
\hline Székesfehérvár város & $12 \%$ & $21 \%$ & $25 \%$ & $24 \%$ & $28 \%$ & $20 \%$ & $4 \%$ & $6 \%$ & $31 \%$ & $29 \%$ \\
\hline Székesfehérvári & $12 \%$ & $23 \%$ & $12 \%$ & $7 \%$ & $31 \%$ & $36 \%$ & $7 \%$ & $11 \%$ & $38 \%$ & $23 \%$ \\
\hline Szekszárdi & $14 \%$ & $21 \%$ & $15 \%$ & $10 \%$ & $22 \%$ & $29 \%$ & $7 \%$ & $10 \%$ & $42 \%$ & $31 \%$ \\
\hline Szerencsi & $18 \%$ & $26 \%$ & $12 \%$ & $7 \%$ & $19 \%$ & $24 \%$ & $14 \%$ & $15 \%$ & $38 \%$ & $29 \%$ \\
\hline Összesen & $14 \%$ & $23 \%$ & $14 \%$ & $11 \%$ & $25 \%$ & $28 \%$ & $8 \%$ & $10 \%$ & $39 \%$ & $27 \%$ \\
\hline
\end{tabular}


A felmért járásokban az egy före jutó helyközi utazások száma 2016 őszén 0,10-0,93 utazás/fö/nap között szóródott (átlag: 0,52 utazás/fö/nap), míg 2008 öszén még 0,16-0,95 utazás/nap/fö (átlag: 0,66 utazás/nap/fö) volt ez az érték. A csökkenés vagy legalábbis a stagnálás - a Gyáli és a Kunszentmiklósi járások kivételével - mindenhol megfigyelhető. A helyközi mobilitás leginkább a Sümegi járásban esett vissza $(0,89 \rightarrow 0,45$ utazás/fő/ nap), amit a Soproni járás $(0,61 \rightarrow 0,32$ utazás/fö/nap) és Székesfehérvár városa $(0,52 \rightarrow$ 0,26 utazás/fö/nap) követ. A felmért járások közül egyébként is kiemelkedő mobilitású Gyáli járásban a napi utazásszám 0,88 utazás/föről emelkedett 0,93-ra, míg a Kunszentmiklósi járásban 0,37 utazás/fó/nap értékről emelkedett a mobilitás a még mindig átlag alatti 0,47-re.

A két időpontban elvégzett felmérések alapján megállapítható, hogy a helyközi közforgalmú közlekedés szervezése terén végrehajtott változtatások hatásai megmutatkoznak az utazók módválasztásában. Így például a megszüntetett autóbuszos kínálat helyét részben átvette a vasút, de az utazók egy másik része a személygépkocsi használatát preferálja inkább. Ezért jelentősen változott - nőtt - a vasúti mobilitás a Gyáli járásban, miközben a helyközi autóbusz használata drasztikusan visszaesett, de nagyon megugrott a személygépkocsis mobilitás is. Például Szeged városának lakói, vagy a Soproni és a Marcali járások lakosai - anélkül, hogy nagyobb arányban használnák a vasutat - inkább személygépkocsival utaznak újabban az autóbusz helyett.

A felmérésekből származó adatok messzemenően összecsengenek a háztartási kikérdezésekkel párhuzamosan a helyközi közforgalmú közlekedési eszközökön végzett utasszámlálásaink eredményeivel. Ezek is visszaigazolják a közszolgáltatási szerződések keretében helyközi utasforgalmat lebonyolító vasúti és közúti személyszállító vállalatok éves beszámolóiban rendre megjelenő problémát ${ }^{2}$ : a népesség demográfiai szerkezetének átalakulásával, az elöregedéssel párhuzamosan egyre csökken az utasok száma (de legalábbis az eladott menetjegyek és bérletek száma). A mérséklődés alapvetően az autóbuszos személyszállításban jelentkezik, ahol - az időközben végrehajtott tarifaváltoztatások ellenére - éves szinten az összes szolgáltatónál összesen alig 1,8\%-kal volt több a közlekedési bevétel 2016-ban, mint 2008-ban. A háztartási megkérdezésekből származó információk szerint a mobilitás viszszaesése a személygépkocsis mobilitás általános csökkenése mellett a helyközi autóbuszos közlekedést is érintette.

Mindazonáltal a legnagyobb mérséklődést a személygépkocsis mobilitás terén tapasztaljuk 2008 és 2016 között. Nemcsak az a feltünő, hogy ebben a közlekedési módban a legeröteljesebb a napi egy főre jutó helyközi utazások számának csökkenése (a felmért járásokban átlagosan 0,37 utazás/nap/fő szintről 0,29 utazás/nap/fö szintre), hanem az is, hogy ez a csökkenés gyakorlatilag az ország minden táját és mindenféle településtípust érintett. (A személygépkocsimozgások száma, azaz a forgalom azért nem csökkent észrevehetően a két vizsgált időpont között, mert - legalábbis a mindkét évben felmért 16 járásban -az átlagos személygépkocsitelítettség csökkenése ellensúlyozta a mobilitás visszaesését.) A személygépkocsik Országos Célforgalmi Mátrixszal modellezett futásteljesítményének növekedéséhez hozzájárult az is, hogy az elmúlt évek során nőtt a személygépkocsis utazások átlagos hossza. Mindez annak ellenére következett be, hogy a jelenlegi modellben kisebb területü forgalmi körzeteket alakítottunk ki. A 2008. évi modellben a forgalmi körzeten belüli utazások egy része így megjelent a 2016. évi modellben rövid, de mégis forgalmi körzetek közötti utazásként. Ezzel együtt az átlagos utazási távolság 2016-ban 45,8 km volt, 5,3 km-rel több, mint 2008. évi felmérésünk idején (1. ábra). Figyelemre méltó, hogy ugyanakkor a forgalmi körzetek területének csökkenésével együtt - mérséklődött az utazások hosszának szórása (44,5 km-ről 30,5 km-re). Az átlagos utazási távolság 2016-ban mintegy 45,8 perces személygépkocsis helyközi utazást jelentett.

${ }^{2}$ A közforgalmú helyközi autóbuszos személyszállitás 2015. évi indokolt költségeinek vizsgálata és a bevételekkel nem fedezett indokolt költségek és az iparági átlagos bevétel arányos nyereség meghatározása. Kutatási jelentés. Témafelelös: dr. Siska Miklós. KTI, 2016 


\section{1. ábra: A helyközi személygépkocsis utazások hosszúsága 2008-ban és 2016-ban}

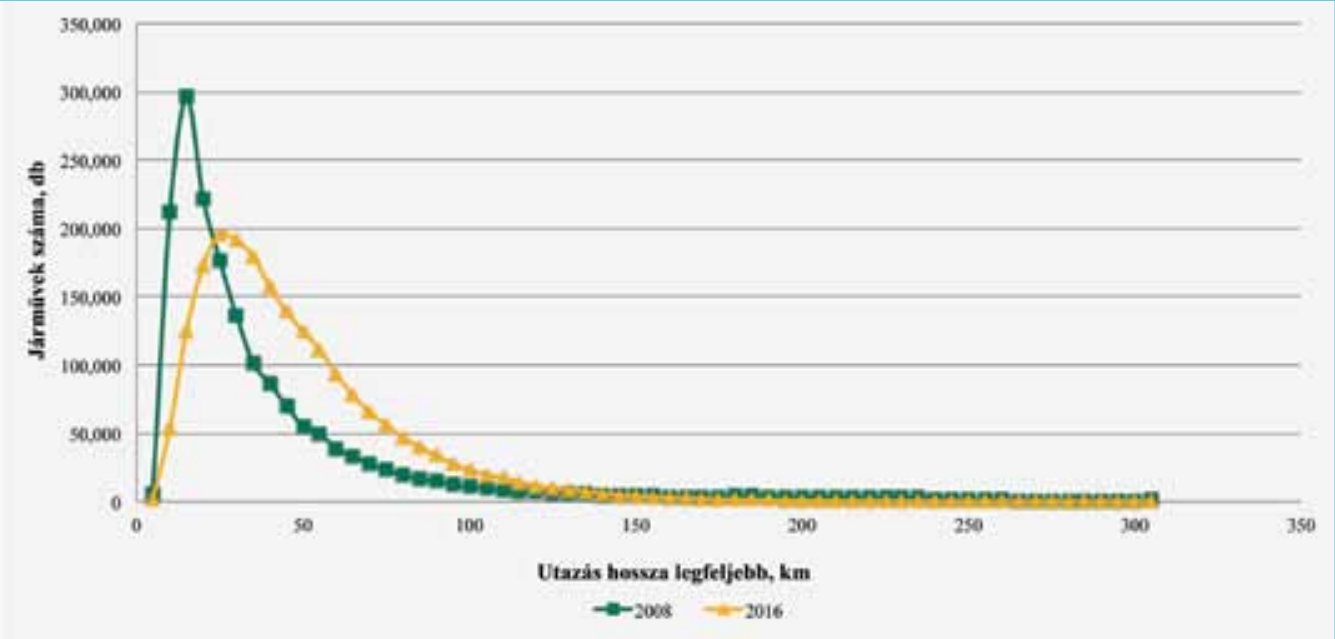

A 2016. évi felmérésünkben vizsgált járásokban a férfiak helyközi személygépkocsis mobilitása (és úgy általában is helyközi mobilitása) nagyobb volt, mint az ugyanott lakó nőké. Ebben nincs változás 2008-cal összehasonlítva. Ugyanakkor a mobilitás számszerü értéke (férfiak: 0,23-1,06 szgk.-mozgás/nap/ fö, nők: 0,06-0,54 szgk.-mozgás/nap/fö) már összességében szignifikánsan alacsonyabb volt 2016-ban, mint a korábbi kikérdezés során az ugyanezekben a járásokban tapasztalt értékek. Az egyes vizsgált járások ebből a szempontból sem mutatnak egységes képet. Vannak, ahol mindkét nem esetében jelentösek az eltérések a két időpont adatai között, s van, ahol csak a nők, s van, ahol csak a férfiak esetében tapasztalunk érdemi változást. Ugyanilyen eredményre jutunk akkor is, ha szegmentálást nem a nemek, hanem az életkori csoportok, iskolai végzettség, gazdasági aktivitás, a család jövedelmi helyzete, vagy akár a személygépkocsihoz hozzáférés alapján végezzük.

A szemléltetés kedvéért az 5. táblázatban összefoglaltuk az összes személygépkocsis mobilitás, illetve a nemek szerinti mobilitás átlagos adatait. A zölddel jelölt járásokban nem változott szignifikánsan az összes személygépkocsis mobilitás, a sárgával jelzett járásokban nem dönthető el egyértelmüen, hogy a változás szignifikáns-e, míg a pirossal jelzett járásokban a két időszakban szignifikánsan eltérnek a személygépkocsis mobilitásra vonatkozó becsléseink a háztartási megkérdezésekből származó minták alapján. Ugyanezekkel a színekkel jelöltük a nemek szerinti egyezőséget és eltérést is. (Mivel a hipotézist, hogy az egy före eső személygépkocsi-mozgások száma nem változott 2008 és 2016 között, az egyes járásokban végzett felmérésekből származó minták segítségével vizsgáltuk, így sem a vizsgált járások összességére, sem pedig országos összesenre nem generáltunk adatot. A válaszokat ugyanis csak járási szinten súlyoztuk nemek, életkor és gazdasági aktivitás szerint, országosan már nem. Ez persze nem befolyásolja azt a következtetésünket, hogy a vizsgált járásokban tapasztaltak az azokhoz hasonló járásokban feltételezhetően érvényesek.)

Amint látható, csak a Szekszárdi járásban tekinthető mindkét nem szempontjából stabilnak az egy főre jutó személygépkocsi-mozgások száma, míg a Gyáli járásban nem beszélhetünk stabilitásról. Érdekes, hogy összességében stabil az átlagosan egy före jutó személygépkocsimozgások száma a Szegedi járásban, de mindez annak az eredője, hogy a nemek szerint különkülön vizsgálva már teljesen eltérő adatokat kapunk. 


\begin{tabular}{|c|c|c|c|c|c|c|}
\hline \multirow{2}{*}{$\begin{array}{l}\text { Kistérség (2008) / Já- } \\
\text { rás (2016) }\end{array}$} & \multicolumn{2}{|c|}{ összesen db/fö } & \multicolumn{2}{|c|}{ nök db/fö } & \multicolumn{2}{|c|}{ férfiak db/fö } \\
\hline & 2008 & 2016 & 2008 & 2016 & 2008 & 2016 \\
\hline Székesfehérvári & 0,42 & 0,43 & 0,27 & 0,26 & 0,53 & 0,61 \\
\hline Szegedi & 0,42 & 0,41 & 0,38 & 0,21 & 0,44 & 0,62 \\
\hline Szekszárdi & 0,38 & 0,40 & 0,23 & 0,24 & 0,54 & 0,57 \\
\hline Szerencsi & 0,35 & 0,33 & 0,25 & 0,22 & 0,43 & 0,46 \\
\hline Ceglédi & 0,25 & 0,24 & 0,16 & 0,12 & 0,33 & 0,36 \\
\hline Hajdúszoboszlói & 0,19 & 0,17 & 0,12 & 0,06 & 0,27 & 0,30 \\
\hline Kisbéri & 0,51 & 0,58 & 0,32 & 0,18 & 0,53 & 0,59 \\
\hline Csornai & 0,52 & 0,47 & 0,39 & 0,25 & 0,60 & 0,68 \\
\hline Hatvani & 0,42 & 0,37 & 0,40 & 0,42 & 0,57 & 0,76 \\
\hline Soproni & 0,30 & 0,25 & 0,08 & 0,05 & 0,13 & 0,23 \\
\hline Szeged város & 0,10 & 0,14 & 0,18 & 0,12 & 0,41 & 0,38 \\
\hline Gyáli & 0,42 & 0,78 & 0,12 & 0,17 & 0,31 & 0,39 \\
\hline Sümegi & 0,46 & 0,32 & 0,31 & 0,17 & 0,37 & 0,32 \\
\hline Kunszentmiklósi & 0,18 & 0,29 & 0,34 & 0,23 & 0,53 & 0,43 \\
\hline Marcali & 0,21 & 0,28 & 0,13 & 0,17 & 0,23 & 0,45 \\
\hline Székesfehérvár város & 0,35 & 0,24 & 0,22 & 0,54 & 0,58 & 1,06 \\
\hline
\end{tabular}

Tekintve, hogy a vizsgálatot mindig csak kétváltozós modellben végeztük, amelynek során a magyarázó változó mindig a korábban említett szegmentálásnak csak egy tényezője volt, szükséges lenne az elemzés megismétlése többváltozós modellek segítségével is. Azonban a jelenleg rendelkezésünkre álló adatállomány (kevesebb, mint 30 járás adata) nem biztosít kellő mennyiségű információt ehhez. Az ilyen módszerek alkalmazásával készült elemzéseket ezért a jövőben célszerü elvégezni.

Az utazási mód megválasztásában sem egyértelmü, hogy milyen irányú módosulások játszódtak le a mindkét időszakban vizsgált járások lakossága körében. 2016-ban továbbra is a személygépkocsi vezeti a sort a helyközi utazásokhoz használt közlekedési eszközök között, részaránya az összes utazásból 54\%. Ezt követi az autóbusz-használat az összes utazás 36\%-ával. Mivel nem mindenhol érhető el az autóbusszal versenyképes vasút (pl. a vasútállomás a településen kívül helyezkedik el, vagy ha van egyáltalán, nincs közvetlen összeköttetése a céltelepüléssel stb.),

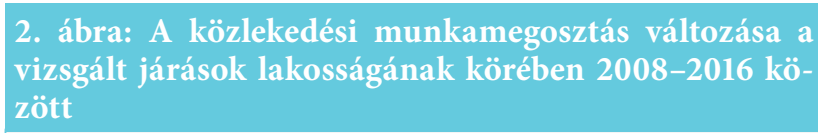

Közlekedési munkamegosztás (2008)

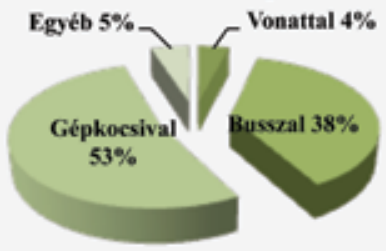

Közlekedési munkamegosztás (2016)

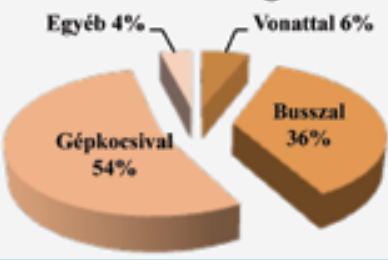


Az összképet azonban árnyalja, hogy - összhangban a mobilitás változásaival - az egyes megyékben eltérően alakult az egyes utazási módok részesedése az összes helyközi utazásban (6. táblázat). Így például amiatt, hogy a Ceglédi járásban összességében csökkent a helyközi mobilitás, miközben a vasúti mobilitás szintje nem változott érdemben, ennek a közlekedési módnak a súlya az összes helyközi utazáson belül jelentősen megnőtt. A Székesfehérvári járásban pedig az autóbuszos helyközi utazások részaránya úgy nőtt viszonylag jelentősen, hogy összességében az egy före jutó napi autóbuszos utazások száma csökkent, csak ez a mérséklődés korántsem volt olyan mértékü, mint a személygépkocsis utazások visszaesése.

A helyközi utazási indokok között 2016-ban messze a legnagyobb értéket a hivatásforgalmi célú utazások teszik ki (az összes utazás 62\%a). Ezt követik a vásárlási célú (az utazások $11 \%$-a) és a munkavégzés céljából lebonyolított helyközi utazások (az összes utazás 8\%-a). Fontosak még természetesen az egészségügyi okból és látogatás céljából lebonyolított (az utazások 7-7\%-a) és ügyintézés miatt szükségessé váló utazások (az összes utazás 5\%-a) is.
Az utazások indokok szerinti megoszlásában jelentős változások zajlottak le összességében és az egyes járásokban is külön-külön (7. táblázat). Ezek a módosulások - hasonlóan a többi közlekedési szokásjellemzőhöz - eltérő irányúak és mértékűek voltak az egyes járásokban. Változatlanul a hivatásforgalmi, a munkavégzéssel és állampolgári ügyek intézésével kapcsolatos utazások teszik ki összességében az összes helyközi utazás mintegy 3/4-ét, azonban egyes körzetekben ezek súlya a korábbi felmérésünkkel összehasonlítva jelentősen megnőtt (pl. Szeged és Székesfehérvár városának lakói körében, elsősorban a munkába járás miatt). Máshol pedig éppen ellenkezőleg, számottevően visszaesett az egészségügyi okból vagy éppen vásárlás céljából lebonyolított helyközi utazások súlyának növekedése miatt (pl.: a Szekszárdi vagy a Gyáli járásban). A látogatás céljából lebonyolított helyközi utazások aránya viszont általában jelentősen csökkent a korábbi adatfelvétellel összehasonlítva.

A helyközi utazások döntő hányadát (2016ban 71\%-át) - szoros összefüggésben az utazás indokával - változatlanul nagy rendszerességgel bonyolítják le. A helyközi uta-

6. táblázat: A közlekedési munkamegosztás változása az egyes járások lakosságának körében 2008-2016 között

\begin{tabular}{|l|c|c|c|c|c|c|}
\hline \multirow{2}{*}{ Kístérség (2008) / } & \multicolumn{2}{|c|}{ Vonattal } & \multicolumn{2}{c|}{ Busszal } & \multicolumn{2}{c|}{ Gépkocsival } \\
\cline { 2 - 7 } & $\mathbf{2 0 0 8}$ & $\mathbf{2 0 1 6}$ & $\mathbf{2 0 0 8}$ & $\mathbf{2 0 1 6}$ & $\mathbf{2 0 0 8}$ & $\mathbf{2 0 1 6}$ \\
\hline Ceglédi & $18 \%$ & $25 \%$ & $30 \%$ & $26 \%$ & $48 \%$ & $40 \%$ \\
\hline Csornai & $2 \%$ & $1 \%$ & $39 \%$ & $45 \%$ & $51 \%$ & $52 \%$ \\
\hline Gyáli & $4 \%$ & $19 \%$ & $46 \%$ & $16 \%$ & $48 \%$ & $56 \%$ \\
\hline Hajdúszoboszlói & $9 \%$ & $6 \%$ & $34 \%$ & $43 \%$ & $52 \%$ & $48 \%$ \\
\hline Hatvani & $2 \%$ & $3 \%$ & $34 \%$ & $39 \%$ & $62 \%$ & $56 \%$ \\
\hline Kisbéri & $1 \%$ & $0 \%$ & $41 \%$ & $43 \%$ & $51 \%$ & $54 \%$ \\
\hline Kunszentmiklósi & $4 \%$ & $7 \%$ & $41 \%$ & $34 \%$ & $53 \%$ & $58 \%$ \\
\hline Marcali & $1 \%$ & $2 \%$ & $42 \%$ & $34 \%$ & $51 \%$ & $62 \%$ \\
\hline Soproni & $4 \%$ & $3 \%$ & $40 \%$ & $32 \%$ & $49 \%$ & $58 \%$ \\
\hline Sümegi & $1 \%$ & $1 \%$ & $41 \%$ & $40 \%$ & $56 \%$ & $56 \%$ \\
\hline Szeged város & $0 \%$ & $5 \%$ & $42 \%$ & $14 \%$ & $57 \%$ & $75 \%$ \\
\hline Szegedi & $0 \%$ & $0 \%$ & $41 \%$ & $47 \%$ & $59 \%$ & $52 \%$ \\
\hline Székesfehérvár város & $7 \%$ & $5 \%$ & $13 \%$ & $21 \%$ & $78 \%$ & $72 \%$ \\
\hline Székesfehérvári & $2 \%$ & $1 \%$ & $47 \%$ & $53 \%$ & $46 \%$ & $41 \%$ \\
\hline Szekszárdi & $3 \%$ & $2 \%$ & $37 \%$ & $38 \%$ & $56 \%$ & $59 \%$ \\
\hline Szerencsi & $21 \%$ & $9 \%$ & $18 \%$ & $26 \%$ & $54 \%$ & $58 \%$ \\
\hline
\end{tabular}


7. táblázat: A helyközi utazások megoszlása az egyes járásokban az utazás indoka szerint, 2008-2016

\begin{tabular}{|l|c|c|c|c|c|c|c|c|}
\hline \multirow{2}{*}{$\begin{array}{l}\text { Kistérség (2008) } \\
\text { Járás (2016) }\end{array}$} & $\begin{array}{r}\text { Hivatásforgalom, } \\
\text { munka, ügyintézés }\end{array}$ & \multicolumn{2}{|c|}{ Vásárlás } & \multicolumn{2}{c|}{ Egészségügyi ok } & \multicolumn{2}{c|}{ Látogatás } \\
\cline { 2 - 9 } & $\mathbf{2 0 0 8}$ & $\mathbf{2 0 1 6}$ & $\mathbf{2 0 0 8}$ & $\mathbf{2 0 1 6}$ & $\mathbf{2 0 0 8}$ & $\mathbf{2 0 1 6}$ & $\mathbf{2 0 0 8}$ & $\mathbf{2 0 1 6}$ \\
\hline Ceglédi & $77 \%$ & $82 \%$ & $6 \%$ & $11 \%$ & $5 \%$ & $5 \%$ & $13 \%$ & $1 \%$ \\
\hline Csornai & $79 \%$ & $84 \%$ & $6 \%$ & $8 \%$ & $7 \%$ & $3 \%$ & $8 \%$ & $4 \%$ \\
\hline Gyáli & $82 \%$ & $71 \%$ & $5 \%$ & $12 \%$ & $5 \%$ & $9 \%$ & $8 \%$ & $7 \%$ \\
\hline Hajdúszoboszlói & $75 \%$ & $88 \%$ & $13 \%$ & $5 \%$ & $4 \%$ & $3 \%$ & $9 \%$ & $5 \%$ \\
\hline Hatvani & $75 \%$ & $72 \%$ & $8 \%$ & $16 \%$ & $2 \%$ & $6 \%$ & $15 \%$ & $6 \%$ \\
\hline Kisbéri & $74 \%$ & $75 \%$ & $9 \%$ & $10 \%$ & $7 \%$ & $11 \%$ & $11 \%$ & $4 \%$ \\
\hline Kunszentmiklósi & $73 \%$ & $58 \%$ & $5 \%$ & $14 \%$ & $10 \%$ & $15 \%$ & $12 \%$ & $13 \%$ \\
\hline Marcali & $70 \%$ & $68 \%$ & $10 \%$ & $8 \%$ & $11 \%$ & $9 \%$ & $9 \%$ & $15 \%$ \\
\hline Soproni & $76 \%$ & $74 \%$ & $9 \%$ & $10 \%$ & $6 \%$ & $6 \%$ & $9 \%$ & $10 \%$ \\
\hline Sümegi & $62 \%$ & $71 \%$ & $9 \%$ & $14 \%$ & $11 \%$ & $7 \%$ & $18 \%$ & $7 \%$ \\
\hline Szeged város & $68 \%$ & $86 \%$ & $3 \%$ & $4 \%$ & $5 \%$ & $7 \%$ & $24 \%$ & $4 \%$ \\
\hline Szegedi & $72 \%$ & $86 \%$ & $21 \%$ & $8 \%$ & $5 \%$ & $5 \%$ & $2 \%$ & $1 \%$ \\
\hline Székesfehérvár város & $56 \%$ & $69 \%$ & $1 \%$ & $5 \%$ & $3 \%$ & $0 \%$ & $41 \%$ & $26 \%$ \\
\hline Székesfehérvári & $79 \%$ & $78 \%$ & $9 \%$ & $16 \%$ & $8 \%$ & $2 \%$ & $5 \%$ & $4 \%$ \\
\hline Szekszárdi & $70 \%$ & $58 \%$ & $11 \%$ & $13 \%$ & $7 \%$ & $18 \%$ & $11 \%$ & $11 \%$ \\
\hline Szerencsi & $69 \%$ & $75 \%$ & $10 \%$ & $14 \%$ & $8 \%$ & $5 \%$ & $14 \%$ & $6 \%$ \\
\hline
\end{tabular}

zások legnagyobb részét (67\%-át) 2008-ban is majdnem napi rendszerességgel tették meg. A heti, havi rendszerességü utazásokat (2008-ban az összes utazás 20\%-át, 2016-ban $18 \%$-át) inkább az egyéb utazási indokokkal összefüggésben teszik meg. Szorosan az utazások rendszerességéhez kapcsolódik, hogy a helyközi személygépkocsis utazások jelentős hányadát valamilyen éves megyei matricával tették meg a felmért járásokban (a napi rendszerességgel utazók 21\%-a használt ilyet). Felmérésünk is azt igazolja vissza, hogy a megyei matrica bevezetésével a matricahasználat még inkább elterjedtté vált 2008-cal összehasonlítva.

\section{5. ÖSSZEGZÉS}

A helyközi mobilitás jelentősen megváltozott 2008-cal összehasonlítva. Nőtt azok aránya, akik egyáltalán nem utaztak másik településre. A helyközi közlekedés szervezése terén végrehajtott változtatások hatásai megmutatkoznak az utazók módválasztásában. A megszüntetett autóbuszos kínálat helyét részben átvette a vasút, az utazók egy másik része a személygépkocsit részesíti elönyben. A leg- nagyobb mérséklődést a személygépkocsival történő utazás terén tapasztaltuk: 0,37 utazás/nap/fö szintről 0,29 utazás/nap/fö szintre. A járműben utazók számának csökkenése, továbbá az utazások hosszának növekedése miatt azonban ez a mérséklődés nem mutatkozik meg a személygépkocsik forgalmában. 2016-ban személygépkocsit használtak leginkább a helyközi utazásokhoz (54\%), ezt követi az autóbusz (36\%). A vasút elmarad az előző kettőtől (6\%). Az utazási indokok között 2016-ban a legnagyobb részt a hivatásforgalmi célú helyközi utazások teszik ki (62\%). Ezt követik a vásárlási célú (11\%) és a munkavégzés céljából lebonyolított (8\%) helyközi utazások. A helyközi utazások döntő hányadát igen nagy rendszerességgel bonyolítják le. A helyközi személygépkocsis utazások jelentős hányadát valamilyen éves megyei matricával tették meg.

\section{FELHASZNÁLT IRODALOM}

[1] Szalai Sándor (szerk.) (1972): The use of time: Daily Activities of Urban and Suburban Populations in Twelve Countries. Mouton \& Co., Hága-Párizs 
[2] Haggett, Peter (2001): Geography: A Global Synthesis. Pearson Education Limited, Harlow

[3] Siska Miklós (2016): Are travel behaviours stable in space and time? WCTR 2016 - Shanghai, 10-15 July, 2016

[4] An Outlook for Europe's Airports.
Facing the Challenges of the 21st Century: ACI-EUROPE, 2010

[5] Siska Miklós és Szabó Tamás (2015): Preferenciák a közlekedési mód megválasztásában Magyarországon. TÉRGAZDASÁG-EMBER III. évf. 3. szám: 81-101.

\section{Evolution of travel habits and their impact on passenger car traffic}

Interurban mobility has changed considerably compared to 2008. The proportion of those who did not travel to another settlement at all has increased. The effects of changes in the organization of interurban transport are reflected in passengers' mode choice. Recently cancelled bus services have partially been taken over by rail, while another group of passengers have preferred travelling by car. In spite of this, the most significant reduction was seen in the use of passenger cars: it decreased from 0.37 trips/ day/person to 0.29 trips/day/ person. However, due to the decrease in the number of travellers in each vehicle and the increase in distances travelled, this decline is not reflected in the total passenger car traffic.

In 2016, passenger cars were used most for interurban journeys (54 per cent), followed by bus transport ( 36 per cent). The railroad accounted for less than the previous two (6 per cent). Considering trip purposes, the most important part of interurban trips in 2016 (62 per cent) was commuting travel. This was followed by shopping-related (11 per cent) and work-related (8 per cent) interurban journeys. The large majority of interurban trips are carried out with considerable regularity. A significant part of the interurban car trips were made using a county-level annual e-vignette.

\section{Die Entwicklung der Verkehrsgewohnheiten und ihre Auswirkungen auf den Pkw-Verkehr}

Die regionale Mobilität hat sich gegenüber 2008 bemerkenswert verändert. Der Anteil derjenigen, die gar nicht in eine andere Siedlung fuhren, zunahm. Die Auswirkungen der Änderungen in der Organisation des regionalen Personenverkehrs spiegeln sich in der Wahl des Verkehrsmittels der Fahrgäste wider. Die Rolle der abgestellten Buslinien wurde teilweise von der Eisenbahn übernommen, während eine andere Gruppe von Passagieren das Reisen mit dem Auto bevorzugt hat. Trotzdem wurde bei der Benutzung von Personenkraftwagen die bedeutendste Reduktion beobachtet: sie sank von 0,37 Fahrten/Tag/Person auf $0,29 \mathrm{Fahrten} / \mathrm{Tag} / \mathrm{Person}$. Allerdings spiegelt sich diese Verringerung aufgrund der sinkenden Zahl der Reisenden in den einzelnen Fahrzeugen und der Zunahme der zurückgelegten Strecken nicht im gesamten Pkw-Verkehr wider.

In 2016 wurden für Regionalfahrten meistens Pkw (54 Prozent) benutzt, gefolgt von Bus (36 Prozent). Die Eisenbahn stand nach diesen beiden zurück (6 Prozent). Der wichtigste Teil der Reisegründe fiel im Jahre 2016 auf den zwischenörtlichen Berufsverkehr (62 Prozent). Darauf folgten einkaufsbezogene (11 Prozent) und arbeitsbezogene (8 Prozent) Fahrten. Die große Mehrheit des Regionalverkehrs wird mit erheblicher Regelmäßigkeit durchgeführt. Ein bedeutender Teil der zwischenörtlichen Pkw-Fahrten wurde mit einer Jahresvignette für bestimmten Komitaten durchgeführt. 